TEME, г. XLII, бр. 4, октобар - децембар 2018, стр. 1219-1233

Претходно саопштење

DOI: $10.22190 /$ TEME1804219N

Примљено: 13. 2. 2018.

UDK 371.14: 004

Ревидирана верзија: 1. 7. 2018.

371.12: 37.02

Одобрено за штампу: 30. 9. 2018.

\title{
INTEGRATING DIGITAL TECHNOLOGIES INTO TEACHING PROCESS
}

\author{
Biljana Novković Cvetković", Dragana Stanojević
}

University of Niš, Pedagogical Faculty in Vranje, Vranje, Serbia

*biljananovkovic74@gmail.com

\begin{abstract}
This paper wishes to highlight great significance of digital technologies that should be implemented to the highest extent possible in the teaching process. Digital literacy and digital competencies in today's highly developed technological world have been recognized as important aspects for the successful implementation of digital technologies in the teaching process. With this in mind, in this paper we tried to answer the questions as to for what purposes teachers use digital technologies the most and how interested the teachers are for the use of digital technologies. The conclusion is that teachers are highly interested in the application of digital technologies in teaching. Out of all the listed items, the teachers mostly used the Internet-based content and Correspondence by e-mail in their work. The research was based on a descriptive investigative method. Surveys and scaling techniques for measuring teachers' attitudes were used. The present research was carried out between March and April 2017.The basic cohort in this research comprised 276 primary school teachers in the cities of Vranje and Nis. The nature of a sample is that of a stratified simple random sample.
\end{abstract}

Key words: digital technologies, digital competences, digital literacy, teaching process, teachers.

\section{ИНТЕГРИСАЊЕ ДИГИТАЛНИХ ТЕХНОЛОГИЈА У НАСТАВНИ ПРОЦЕС}

\footnotetext{
Апстракт

Радом се жели истаћи велики значај дигиталних технологија које би се у што већој мери имплементирале у наставни процес. Дигитална писменост и дигиталне компетенције у данашњем, технолошки високо развијеном, друштву препознате су као важни аспекти за успешну имплементацију дигиталних технологија у наставни процес. У том смислу, у раду смо покушали да одговоримо на питања у које сврхе наставници највише употребљавају дигиталне технологије и колика је заправо заинтересованост наставника за употребу дигиталних технологија. Закључак је да наставници имају велико интересовање за примену дигиталних технологија у настави. Од свих наведених ставки наставници у свом раду највише користе интернет садржаје и коресподенцију електронском поштом. Истраживање
} 
се заснива на дескриптивној научноистраживачкој методи. Примењена је техника анкетирања и техника скалирања за испитивање ставова наставника. Истраживање је спроведено у периоду март-април 2017. год. Основни скуп овог истраживања чинило је 276 наставника̂ основних школа града Врања и Ниша. Узорак је стратификованог једноставнослучајног карактера.

Кључне речи: дигиталне технологије, дигиталне компетенције, дигитална писменост, наставни процес, наставници.

\section{INTRODUCTION}

It is an undisputed fact that school is influenced by social, economic and technological developments, as it cannot be denied that school it self impacts those developments by accelerating the evolution of civilization. Each country strives to put education and school on wholesome grounds considering that knowledge is the key factor in the development of any society, its economy and culture in particular.

The last decade of the twentieth century came up with the term prevailing all areas of society, this being "the digital". Digital age, digital technologies, digital competences, digital education, etc. 'Digital technologies (nowadays collectives referred to as information and communication technologies, ICT) have inhabited all areas of society and the world at large, and hence it would not be possible to imagine any aspect of our life without such technologies' (Ilić, Nedić, 2014). The digital age has inevitably driven the transformation of a classic learning and teaching paradigm with the help of traditional media into a new paradigm shaped by digital media technology.

The use of digital technologies in the teaching process has been the subject of many studies. A number of studies have shown that the greatest obstacle to the integration of digital technologies into teaching process are poor competencies on the part of teachers, that is, insufficient training of teachers to apply digital technologies in the classroom. This means that developed digital skills are a prerequisite for the application of digital technologies. The fact that teachers have a positive attitude to the use of digital technologies and that the main obstacle to the application of digital technologies for them is the lack of digital skills has been demonstrated by many studies - Innovative learning environmentsfor schools (Ramboll Management , 2004), The ICT Impact Report (Balanskat \& Blamire, 2007), Sipilä (2014), Lindberg et al. (2016). A study carried out by Andevski et al. (2014) showed that the large number of teachers (up to 80\%) use the Internet for teaching.

\section{DIGITAL TECHNOLOGIES IN TEACHING}

Digital technology has a powerful effect on all aspects of society. However, 'integrating digital technologies into current teaching curricula 
is a complex process influenced by numerous factors' (Balanskat, Blamire $\&$ Kefala, 2006). `Andreas Schleicher, Head of the OECD Department of Education, claims that in order to fully use the potentials of digital technologies, each country must make sure its teachers and educators are in the front line when it comes to preparing and introducing such changes (OECD, 2015). 'New (digital) technologies enhance the possibility to acquire knowledge and thus become serious competition to the traditional institution of school' (Lav, Pelgrum \& Plomp, 2008).

In order for the implementation of digital technologies in teaching as an innovation process to become part of education activities, it is necessary to be able to investigate and embrace change in school, to experiment, to consider needs, as these constitute the grounds for innovation. The pace at which innovation is embraced in a school depends on several factors - the intensity of innovation spread, the contribution of innovation to the increased quality of teaching, diffusion of innovative effects from renowned schools, that is, the pace of innovation exchange between schools of the same or similar type. 'New teaching technologies are neither, nor can they be, a complete negation of existing practice, they can not be promoted on the ruins of verified values, but through the creative synthesis of existing and new teaching technologies`(Vasilijević, 2017).

The manual on Digital Strategies for Educational Transformation recommends including the use of ICT and digital media in the curriculum through special tasks in all subjects with the purpose of developing digital fluency (European Commission/ICT Cluster 2010, p. 29).

The "Strategy for the Development of Education in Serbia by 2020" emphasizes the significance of digital technologies for the overall development of the education system. However, the first official document dealing with the integration of digital and online learning into the education system in a comprehensive way was adopted by the National Education Council in 2013, when the public was presented with the "Guidelines for Improving Information and Communication Technologies in Education". It is recommended for the teachers to possess computer, information, digital and media literacy, and to be familiar with modern concepts, methods and tools in their respective teaching areas, which assume the use of ICT (National Education Council of the Republic of Serbia, 2013).

However, it soon became apparent that the key professional development for teachers that supports the integration of digital technologies into their classrooms would not happen at once, and once it did begin it would not be the process that ends there. In fact, it turned out that teachers need continuous support to upgrade their skills in line with development trends. This means that schools and professional training providers must enable all teachers to acquire skills and knowledge in order to successfully integrate digital technologies into their daily practice. In addition, teachers must work on their development autonomously by using the available 
information sources and the support of the environment, as well as free online resources (Ministry of Education, Science and Technological Development, 2017).

\section{Digital Literacy and Digital Competencies of Teachers Prerequisite for Using Digital Technologies}

An accelerated development of knowledge and a dramatic increase in the quantity, availability and variety of information are a dominant characteristic of the world in which we live. The main "culprit" for such state is the easiness with which we produce, transform and manipulate digital electronic information. Digital technologies based on digital information have created a new view of the world in the last decade and have drastically changed the way in which we become informed, learn and communicate. Social development will inevitably move in the direction of increased digitalization. All these result in digital literacy being recognized as a fundamental survival skill, crucial for our successful realization within our life roles in the abruptly changing world.

What does being digitally literate mean? Definitions of digital literacy generally include: the use of information and communication technologies, searching, storing and sending digital information, creating, processing and displaying digital information. This means that a person can be called digitally literate if they possess the knowledge of where and how they can get information and if they possess the ability to virtually manipulate data, i.e. this is a person who knows how to save or send information and create and display information with the use of digital technologies.

Nonetheless, digital technologies are rapidly changing and advancing. A few years ago anyone possessing basic computer skills was considered a digitally literate person. Typing the text in Word, creating tables in Excel, creating presentations in PowerPoint, etc. Today, the basic skills involve knowing the Internet and its services, particularly communication via e-mail. The search engine results are useless. It is not only important to find information online, but having the skill how to use it, or how to turn it into knowledge.

Paul Gilster defines digital literacy as a possibility to access network computer sources and use them (Glister, 1997). `Špiranec equates digital literacy with the term Internet literacy by which he implies the ability to read and understand hypertext or multimedia text, including the ability to make judgement on online resources, search the Internet, manage multimedia material, communicate online' (Vrkić-Dimić, 2014). 'Digital literacy involves more than the mere ability to use software or operate a digital device; it includes a large variety of complex cognitive, motor, sociological and emotional skills which the users need in order to function effectively in digital environments`(Eshet-Alkalai, 2004). 
Some authors expand the concept of digital literacy and connect it with media literacy (Erstad, 2010, ISPL, 2006, Jenkins et al., 2007, Špiranec, 2003. ) or information literacy (Bindé, 2007, Catts, Lau, 2008; Kralj, 2006; acc. to Vrkić-Dimić, 2014).

'In order to gain knowledge on digital literacy, Gilster thinks we need to have certain competencies such as:

- Critical thinking runs the use of what we find on the web. Forming a balanced evaluation and differentiating between content and presentation is the key.

- The next competency follows from critical thinking. Some people need to employ target reading using the model of electronic word - hypertext or hypermedia. The journey through text is enriched with choices.

- Consequently to the foregoing, one should learn how to assemble knowledge. It is necessary to learn how to assemble the amount of critical information from scattered sources. One should choose the environment in which it is possible to work and shape it with Internet tools.

- The development of Internet search skills is the last key competency of digital literacy. It is important to come up with various strategies and ways in which to use search engines that go through countless information and pages and recognize what matters` (Gilster, in Pool 1997, p.6).

Bawden believes that Gilster failed to list all the competencies and he therefore completed them with the following:

- Managing the so-called "multimedia flow" is also necessary, using information filters and agents.

- Creating a personal information strategy coupled with the selection of sources and the mechanisms for information supply.

- Being aware of other's presence on the Internet and extended possibility to contact them for help or a discussion.

- Being able to understand a problem and come up with a set of questions that help resolve information needs.

- Understanding the support of traditional forms of content with the use of Internet ads`. (Bawden, 2001, p.232).

In the context of using digital technologies and new forms of literacy, we often come across the concept of digital competence.

What do we mean by digital competence? Digital competence is considered a wider concept than digital literacy by many authors. Digital competence is cited as one of the eight key competences for lifelong learning as defined by European Union in order to successfully deal with challenges pertaining to the development of knowledge society and the 
world market. 'Digital competence refers to the ability to safely and critically use information and communication technology for work, in one's personal and social life, as well as communication. Its key elements are the basic information and communication skills and competences: using a computer to find, evaluate, store, create, display and exchange information and develop joint networks on the Internet (European Commission, 2006, p. 14).

According to Ilomäkiet et al. digital competence involves technology related skills. 'Over the past few years several terms have been used to describe skills and competences in using digital technologies, such as information technology skills, technological skills, 21st century skills, information literacy, digital literacy and digital skills' (Ilomäki, Kantosalo \& Lakkala, 2011).

„A set of knowledge, skills, attitudes, abilities and strategies required for quality use of ICT and digital media with the purpose of a though-out, flexible and safe improvement of a teaching and learning process and other activities related to teaching profession in online and offline environments is what constitutes digital competence according to Ferrari "(Ferrari, 2012, p.32).

Krumsvik (2007) provides a definition of digital competence particularly for teachers: "Digital competence is the ability of a teacher to use ICT with good pedagogical and didactic information and communication technology. This means that a teacher needs to make decisions on what type of digital tools to use in each teaching situation, how to use it and why. Krumsvik notes that it is essential to develop this kind of awareness in the course of initial teacher training" (Krumsvik, 2007, p. 68).

The necessity of having digital competence particularly in teachers was recognized by the Ministry of Education, Science and Technological Development of the Republic of Serbia in 2017. when it published a "Digital Competence Framework - Teacher for Digital Age", a brochure that aims to help teaching staff at all levels of education, including universities, to reflect on their current practice and identify the next steps in their professional development of a "teacher for a digital age". The framework has been designed for individual use by teachers who wish to identify the areas in which they want to develop.

'The framework identifies 30 digital competencies classified into eight broad categories:

1. Searching, accessing, storing and managing information

2. Searching, adapting and creating digital content for teaching and learning

3. Managing digital content for teaching and learning and the sharing thereof

4. Managing a learning environment

5. Teaching and learning 
6. Formative and summative assessment, recording, keeping track and reporting of students' progress

7. Communication and cooperation in online environment

8. Ethics and safety

The listed competences overlap to an extent, but they are independent. Three levels of use have been identified for each competence: (1) basic, (2) intermediate and (3) advanced (Šćepanović et al., 2017).

\section{METHODS}

The aim of this study is to investigate to what extent digital technologies are used in teaching. More precisely, in what ways and for what purposes teachers use digital technologies. The task is to establish the attitudes of teachers, that is, the intensity of teacher's interest in the use of digital technologies in teaching, on the one hand, and to determine similarities and differences in the interest of teachers for the use of digital technologies in teaching in relation to teacher's gender and work experience, on the other. In this sense, the following hypothesis has been suggested: "Respondents show positive attitude towards the use of digital technologies in teaching in total and there are no statistically significant differences between respondents' attitudes towards adopting and using digital technologies in teaching based on the respondents' gender and work experience".

The research was based on a descriptive investigative method. Surveys were used (for the collection of basic data) as well as the scaling technique to examine teachers' attitudes.

The present research was carried out between January and February 2017.The basic cohort in this research comprised 276 primary school teachers in the cities of Vranje. The nature of a sample is that of a stratified simple random sample.

The data was processed using a SPSS software pack by calculating a Chi-square.

\section{RESULTS AND DISCUSSION}

In order to determine the degree of teachers' interest in the application of digital technologies in teaching process, we designed a five-point scale with values ranging from 1 to 5 stating the following: 'extremely uninterested', 'mostly uninterested', 'undecided', 'extremely interested' and 'extremely interested', based on which we shall determine the degree of teachers' interest. 
Table 1 Attitude intensity regarding teachers' interest to adopt and apply digital technologies in teaching

\begin{tabular}{lcrr}
\hline Interest intensity & Value & Count & Percent \\
\hline extremely uninterested & up to 1.5 & 3 & 1.10 \\
mostly uninterested & from 1.6 to 2.5 & 18 & 6.59 \\
undecided & from 2.6 to 3.5 & 45 & 16.48 \\
mostly interested & from 3.6 to 4.5 & 123 & 45.05 \\
extremely interested & from 4.6 to 5.0 & 84 & 30.77 \\
\hline
\end{tabular}

As Table 1 shows, positive attitude regarding teachers' interest in the use of digital technologies in teaching prevails. Many more teachers claimed to be interested in the application of digital technologies compared to those uninterested. The results show that teachers declared themselves as mostly interested in the application of digital technologies in teaching, as declared by 123 teachers or $45.05 \%$ or extremely interested, as declared by 84 teachers, i.e. $30.77 \%$. On the other hand, 18 teachers, i.e. $6.59 \%$ were mostly uninterested, while only 3 teachers, i.e. $1.10 \%$ were extremely uninterested. The number of undecided teachers was 45 , i.e. $16.48 \%$.

The respondents were then presented with a Likert-type questionnaire with seven statements, which they completed by answering the questions whether and how they used digital technologies in teaching regarding each statement. All the items ranging from 1 to 5 (from the lowest to the highest value) had the mean closer to the upper values. All the values of the $\chi^{2}$ test that are statistically significant by reaching 0.001 , as well as the skewness values with the minus sign further support such conclusion. In addition, all skewness values have a minus sign which is another suggestion that this is the case of a positive skewness in score distribution.

Table 2 Dimensions of descriptive statistics subscale

\begin{tabular}{lcccccc}
\hline Statements & $\mathrm{M}$ & $\mathrm{SD}$ & $\mathrm{Sk}$ & $\mathrm{Q}$ & $\mathrm{Chi}$ & $\mathrm{P}$ \\
\hline Word processor software & 3.72 & 1.05 & -0.44 & -0.59 & 88.23 & 0.00 \\
Keeping electronic record of students' & 3.76 & 1.06 & -0.55 & -0.46 & 92.04 & 0.00 \\
grades & 3.81 & 0.98 & -0.53 & -0.15 & 119.28 & 0.00 \\
Searching the Internet & 3.41 & 1.08 & -0.23 & -0.75 & 71.44 & 0.00 \\
Creating multimedia content for & 3.12 & 1.11 & 0.05 & -0.83 & 59.87 & 0.00 \\
teaching purposes & 3.44 & 1.01 & -0.22 & -0.46 & 95.62 & 0.00 \\
Creating PowerPoint presentations & 3.79 & 0.92 & -0.28 & -0.63 & 129.20 & 0.00 \\
\hline $\begin{array}{l}\text { Searching web sites for professional } \\
\text { development }\end{array}$ & & & & &
\end{tabular}

There is not much disparity between the mean values for the listed items. Searching the Internet ended up first with M-3.81. 'Modern-day media, Internet in particular, change all aspects of global and personal 
life. 'New (digital) technologies expand the possibility to acquire knowledge and thus become a serious competition to traditional institution of school. Compared to traditional teaching aids (chalk, board and/or OHP) and a teacher as the (only) disseminator of knowledge, the means of new (digital) technologies (above all, a computer) are more accessible to anyone, in terms of both form and content ' (Starčević, 2013, p.220).

'During the last two decades, the Internet and digital technology have become part of everyday life for people all over the world' (Livingstone et al., 2011; Popadić and Kuzmanović, 2013; OFCOM, 2015 acc. to Kuzmanović et al., 2016, p.33). Internet-based content was reported to be used for lesson preparation by $62 \%$ of respondents in the research conducted in Novi Sad (Bulatović, Bulatović \& Arsenijević, 2011).

This is followed by Correspondence by e-mail with the largest M3.79 , which is not surprising considering that e-mail correspondence has readily been greeted by many people. Keeping electronic record of students' grades and Word processor software with their respective means of M-3.76 and M-3.72 immediately followed, whereas Creating Power Point presentations and Creating multimedia content for teaching purposes with M3.12 and M-3.41 respectively, ended up last.

Attitudes of Teachers to Exploring and Implementing Digital Technologies in Teaching in Relation to the Variable Gender

Table 3 presents the results of the interconnectedness of the variable gender of teachers (independent variable) and the resulting cumulative value (defined cumulative Index) attitudes of teachers for the introduction and the implementation of somedigital technologies in teaching (the dependent variable).

The obtained results show that there were no significant differences in the direction and intensity distribution of attitudes for the introduction and the implementation of some digital technologies in teaching.

Table 3 Gender of teachers and intensity of attitudes about interest in introduction and implementation of digital technologies in teaching

\begin{tabular}{lcccccc}
\hline & \multicolumn{5}{c}{$\begin{array}{l}\text { Intensity of teachers' interest for introduction and } \\
\text { implementation of digital technologies }\end{array}$} \\
\cline { 2 - 6 } Gender & $\begin{array}{c}\text { Extremely } \\
\text { indifferent }\end{array}$ & $\begin{array}{c}\text { Mostly } \\
\text { indifferent }\end{array}$ & Undecided & $\begin{array}{c}\text { Mostly } \\
\text { interested }\end{array}$ & $\begin{array}{c}\text { Extremely } \\
\text { interested }\end{array}$ & \\
\hline Male & 0 & 6 & 30 & 24 & 9 & 69 \\
& 0.00 & 8.70 & 43.48 & 34.78 & 13.04 & \\
Female & 3 & 12 & 66 & 99 & 39 & 219 \\
& 1.37 & 5.48 & 30.14 & 45.21 & 17.81 & \\
\hline Total & 3 & 18 & 96 & 123 & 48 & 288 \\
& 1.04 & 6.25 & 33.33 & 42.71 & 16.67 & \\
\hline
\end{tabular}

Pearson Chi-square: $6.66459, \mathrm{df}=4, \mathrm{p}=.154739$ 
Such conclusions suggesting obtained Chi-square (Pearson Chi-square $=6.66459)$, which along with four degrees of freedom $(\mathrm{df}=4)$ were not statistically significant in any of the usual level of testing statistical significance of differences: 0.01 even on 0.05 , since the $\mathrm{p}$-level $=.154739$. Attitudes of teachers to introduction and implementation ofdigital
technologies in teaching in relation to the variable work experience

Table 4 presents the results of the mutual relationship between the variables work experience of teachers (independent variable) and obtained cumulative value (defined Index) of teachers'attitudes for introduction and the implementation of some digital technologies in teaching (the dependent variable).

Table 4 Work Experience of Teachers and the Intensity of Attitudes about Interest for the Introduction and Implementation of Digital Technologies in Teaching

\begin{tabular}{|c|c|c|c|c|c|c|}
\hline \multirow[t]{2}{*}{$\begin{array}{l}\text { Work } \\
\text { experience }\end{array}$} & \multicolumn{5}{|c|}{$\begin{array}{l}\text { Intensity of teachers' interest for introduction and } \\
\text { implementation of digital technologies }\end{array}$} & \\
\hline & $\begin{array}{l}\text { Extremely } \\
\text { indifferent }\end{array}$ & $\begin{array}{c}\text { Mostly } \\
\text { indifferent }\end{array}$ & Undecided & $\begin{array}{c}\text { Mostly } \\
\text { interested }\end{array}$ & $\begin{array}{l}\text { Extremely } \\
\text { interested }\end{array}$ & \\
\hline \multirow{2}{*}{$\begin{array}{l}\text { Up to } 10 \\
\text { years }\end{array}$} & 0 & 3 & 12 & 27 & 12 & \multirow[t]{2}{*}{54} \\
\hline & 0.00 & 5.56 & 22.22 & 50.00 & 22.22 & \\
\hline From 10 to & 3 & 3 & 27 & 57 & 12 & \multirow[t]{2}{*}{102} \\
\hline 20 years & 2.94 & 2.94 & 26.47 & 55.88 & 11.76 & \\
\hline From 20 to & 0 & 9 & 30 & 33 & 9 & \multirow[t]{2}{*}{81} \\
\hline 30 years & 0.00 & 11.11 & 37.04 & 40.74 & 11.11 & \\
\hline \multirow{2}{*}{$\begin{array}{l}\text { Over } 30 \\
\text { years }\end{array}$} & 0 & 3 & 18 & 6 & 12 & \multirow[t]{2}{*}{39} \\
\hline & 0.00 & 7.69 & 46.15 & 15.38 & 30.77 & \\
\hline \multirow[t]{2}{*}{ Total } & 3 & 18 & 87 & 123 & 45 & \multirow[t]{2}{*}{276} \\
\hline & 1.09 & 6.52 & 31.52 & 44.57 & 16.30 & \\
\hline
\end{tabular}

Insight into the presented results shows that there are statistically significant differences in the direction and intensity distribution of attitudes of teachers regarding introduction and implementation of digital technologies in the individual work in teaching, considering the experience of teachers. Such conclusions suggesting obtained Chi-square (Pearson Chi-square $=35.4364$ ), which along with twelve degrees of freedom $(\mathrm{df}=12)$ were statistically significant at the level of testing statistical significant difference of 0.01 , because the p-level $=.000401$.

It is evident that younger teachers expressed views of major interest in exploring and implementing particular digital technologies of work in teaching, than older teachers. It is thus evident that $72.22 \%$ of teachers with under 10 years of work experience exert positive attitudes, and only $5.56 \%$ 
negative and $22.22 \%$ undecided, while the teachers who have over 30 years of experience much less those with positive attitudes - only $46.15 \%$, much more undecided with $-46.15 \%$ and slightly more negative attitudes $-7.69 \%$.

'Teachers' attitudes towards technologies in teaching are highly variable and age and experience dependent, thus leading us to the conclusion that a wider and more complex comprehension is present in younger teaching staff, that is in persons who extensively use digital technologies in their work' (Braš Roth et al., 2014; Džigurski et al., 2013).

\section{CONCLUSION}

The set of significant factors affecting the degree of innovation applicability in teaching certainly include teachers' interest to apply certain innovation in their work. Interest is indeed an internal drive of human activity. A greater interest in teachers and a developed positive attitude toward innovation are prerequisite for the innovation to find wider use in our schools (Novković-Cvetković, 2017).

The application of digital technologies in education is of key importance in modernizing the teaching process which involves more efficient, economic and effective teaching.' With the use of digital technologies the content of teaching material becomes more apparent, while internal and external motivation increase and teaching becomes more varied. This also involves spontaneous increase of teachers' competences to use ICT, and the possibility for increased participation of students in the learning process' (Džigurski et al. 2013).

In this paper we demonstrated that teachers have a great interest in using digital technologies in teaching. Out of all the listed items, the teachers mostly use Internet-based content in their work which listed at number one with $\mathrm{M}=-3.81$, which is understandable since the Internet is widely used nowadays. This gigantic network offers all the content required for teaching purposes, online courses for professional development and many other benefits.

This was followed by Correspondence by e-mail with the greatest M-3,79. Correspondence by e-mail has had a huge echo with people and is among the top means of communication. Keeping electronic record of students' grades and Word processor software with their respective means of M-3.76 and M-3.72 immediately followed, whereas Creating Power Point presentations and Creating multimedia content for teaching purposes with M-3.12 and M-3.41 respectively ended up last. Creating Power Point presentations and Creating multimedia content require skill and the mastery of the Power Point programme. Insufficient training of teachers and greater efforts on their part to master this programme were probably the reasons why these two items ended up in the last place. 
Our initial hypothesis was partially confirmed. Teachers show great interest in the use of digital technologies in their work and there are no statistically significant differences regarding the gender variable, however; we have established statistically significant differences with regard to the experience, i.e. years of teaching. Younger teachers expressed greater interest in the application of digital technologies in teaching compared to their elderly colleagues.

When it comes to quality of education, teacher training is of utmost importance. In order to make teaching more up-to-date, it is necessary to introduce modern media in the teaching and educational process. The use of media (traditional and digital) in the teaching process is the road to gaining media and digital literacy, which is essential in the modern-age world considering the role and the significance of media in human life (Ibrahimbegović -Tihak, 2015, p.132). 'New (digital) technologies expand the possibility to acquire knowledge and thus become serious competition to the traditional institution of school. In this regard, teacher competences remain vital to upgrading this process'(Law, Pelgrum, Plomp, 2008).

\section{REFERENCES}

Andevski, M. Vidaković, M., Arsenijević, O. (2014). [Internet in teaching and learning]. Proceedings from the International Conference of the Singidunum University, Belgrade: Synthesis, p.368- 374. DOI: 10.15308/sinteza-2014-368-374

Balanskat A., Blamire R., Kefala S. (2006). The ICT Impact Report, European Schoolnet.

Balanskat A., Blamire R. (2007), ICT in Schools, European Schoolnet.

Bawden, D. (2001). Information and Digital Literacies: A Review of Concepts. Journal of Documentation.Vol 57, 2. https://doi.org/10.1108/EUM0000000007083

Bindé, J. (2007): According to knowledge societies. Zagreb: Educa

Braš-Roth, M., Markočić-Dekanić, A., Ružić, D. (2014). ICILS 2013, [Preparing for Life in the Digital Age]. Zagreb: National Center for External Evaluation of Education - PISA Center.

Bulatović, LJ., Bulatović, G., Arsenijević, O. (2011). [Technology, Informatics and Education, TIO 6. Media literacy - the basis of learning in the age of digital technologies]. International Symposium, Technical Faculty Cacak.[online] Retrived from: http://www.ftn.kg.ac.rs/konferencije/tio6/radovi/2)\%20Pedagoske $\% 20$ dimenzije \%20drustva\%20ucenja\%20i\%20znanja/PDF/212\%20Ljiljana\%20B ulatovic.pdf. Accessed 17.10.2017.

Catts, R., Lau, J. (2008). Towards Information Literacy Indicators. Paris: UNESCO. Information for All Programme (IFAP). [online] Retrived from

https://unesdoc.unesco.org/ark:/48223/pf0000158723 Accessed 5.9.2017.

Džigurski, S. Simić, S. Marković, S. Šćepanović, D. (2013). [Research on the use of information and communication technologies in schools in Serbia]. [online] Retrivedfrom: http://socijalnoukljucivanje.gov.rs/wp-content/uploads/ 2014/06/Istrazivanje-o-upotrebi-IKT-u-skolama-u-Srbiji-jun-2013.pdf. Accessed 11.12.2017. 
European Commission/ICT Cluster, 2010. Learning, Innovation and ICT lessons learned by the ICT cluster Education \& Training 2010 programme. Brussels: ICT Cluster. .[online] Retrived from: http://www.europarl.europa.eu/portal/en Accessed 21.8.2017.

European Commission (2006). Key Competencies for Lifelong Learning: A European Reference Framework. Directorate-General for Education and Culture. [online] Retrived from: http://www.erasmusplus.org.uk/file/272/download

Erstad, O. (2010). Educating the Digital Generation. Nordic Journal of Digital Literacy, 1, 56-70.

Eshet-Alkalai, Y. (2004). Digital literacy: A conceptual framework for survival skills in the digital era. Journal of Educational Multimedia and Hypermedia, 13(1), 93. [online] Retrived from: https://www.openu.ac.il/personal_sites/download/Digitalliteracy2004-JEMH.pdf . Accessed 11.5.2017.

Ferrari, A., (2012). Digital Competence in Practice: An Analysis of Frameworks, Institute for Prospective Technological Studies. European Commission Joint Research Centre.

Gilster, P. (1997). Digital Literacy. New York [et al.]: Wiley Computer Pblishing.

Jenkins, H., Clinton, K., Purushotma, R., Robison, A. J. \& Weigel, M. (2007). Confronting the Chalenges of Participatory Culture: Media Education for the 21st Century. Chicago: The MacArthur Foundation.[online] Retrived from: https://www.macfound.org/media/article_pdfs/JENKINS_WHITE_PAPER.PDF Accessed 31.7.2017.

Ibrahimbegović-Tihak, V. (2015). [Competencies of teaching staff in $\mathrm{BiH}$ as an element of the development of media literacy]. Media Literacy in the Digital Age.131-159.

Ilić, V., Nedić,V. (2014). [Digital Age and traditional art media in the teaching of fine arts]. Proceedings of the TIO, FTN Čačak. [online] Retrived from: http://www.ftn.kg. ac.rs/konferencije/tio2016/Knjiga\%20rezimea\%20TIO\%202014.pdf Accessed 25.5.2011.

ISPL, (2006). Information Society and Education: Linking European Policies. Luxemburg: Office for Official Publications of the European Communities.[online] Retrived from:http://ec.europa.eu/information_society/activities/ict_psp/documents/indepen dent_living.pdf Accessed 28.01.2017.

Kralj, L. (2006). [Croatia's readiness for e-learning - what is the potential of elearning education]. Edupoint (electronic edition), 46 (6).[online] Retrived from: http://edupoint.carnet.hr/casopis/46/clanci/2.html . Accessed 25.12.2017.

Krumsvik, R.J. (2007). Skulenog den digital elaring srevolusjonen. Oslo: Universitetsforlaget.

Kuzmanović, D., Lajović, B., Grujić, S. \& Medenica, G. (2016). [Digital violence prevention and response]. Ministry of Education, Science and Technological Development of the Republic of Serbia and Pedagogical Society of Serbia, Cicero, Belgrade, p.33.

Law, N., Pelgrum, W. J., \& Plomp, T. (2008). Pedagogical practices and ICT use around the world: Findings from an international comparative study (CERC Studies in Comparative Education), Hong Kong/Dordrecht: Comparative Education Research Centre, the University of Hong Kong/Springer.

Livingstone, S., Haddon, L., Görzig, A. \&Ólafsson, K. (2011). Risks and safety on the internet:The perspective of European children. Full Findings. LSE, London: EU Kids Online. 
Lindberg, J. O., Olofsson, A. D., \& Fransson, G. (2016). Contrasting views: Student and teacher perceptions on ICT in education. In ICICTE 2016, International Conference on Information and Communication Technologies in Education, Rhodes, Greece, 7-9 July, 2016 (pp. 1-10). [online] Retrived from: http://umu.diva-portal.org/smash/get/diva2:967758/FULLTEXT01.pdf .Accessed 15.6.2017.

Ministry of Education, Science and Technological Development (2017). Digital Competence Framework - Digital Age Teacher. Belgrade.

National Educational Council of the Republic of Serbia (2013). [Guidelines for improving the role of ICT in education]. Beograd. [online] Retrived from: https://www.cipcentar.org/i_roditelji_se_pitaju/PDF/strategija/Smernice\%20IKT.p df Accessed 25.4.2017.

Novković-Cvetković, B. (2017). Innovative designs in teaching work for the improvement of processes. Yearbook of the Faculty of Education in Vranje, 8(1), 177-190.

OECD (2015) 'Students, Computers and Learning Making the Connection'. OECD Publishing.[online] Retrived from: https://www.oecd-ilibrary.org/education/ students-computers-and-learning_9789264239555-en Accessed 15.06.2017.

Ofcom (2015). Children and parents: Media use and attitudes - report. .[online] Retrived from: https://www.ofcom.org.uk/_data/assets/pdf_file/0024/78513/childrens_ parents_nov2015.pdf Accessed 15.06.2017.

Pool, C. (1997). A conversation with Paul Gilster. Educational Leadership, 55 (3), 6-11.

Popadić, D. \& Kuzmanović, D. (2013).[The use of digital technology, the risks and the representation of digital violence among students in Serbia].[online] Retrived from:http://sbn.mpn.gov.rs/clientpub/uploads/Digitalno\%20nasilje-Izvestaj\% 202013.pdf Accessed 25.12.2017.

Ramboll Management(2004) 'Study on Innovative Learning Environments in School Education, Final Report', Denmark: Ramboll Management. .[online] Retrived from:http://compcurric15.pbworks.com/w/file/fetch/93786071/Grammar\%20of\%2 0Schools.pdf Accessed 08.11.2017.

Sipilä, K. (2014). Educational use of information and communications technology: Teachers' perspective. Technology, Pedagogy and Education, 23(2), p.225-241.

Špiranec, S. (2003). [Information literacy is the key to lifelong learning]. Edupoint (electronic edition), 17 (3).[online] Retrived from: http://edupoint.carnet.hr/casopis/17/clanci/1.html Accessed 25.9.2017.

Starčević, N. (2013). [Media education - the world's road map for saturated media]. Digital Media Technologies and Social-Educational Changes 3. Faculty of Philosophy, University of Novi Sad, p.217-223.

Šćepanović, D., Marjanović, U., Korać, I., Stefanović, D. (2017). [Digital competences of university teachers]. XXIII Joint development trends: "The position of higher education and science in Serbia", Zlatibor.

Vrkić-Dimić, J. (2014). Contemporary forms of literacy. [School Newsletter-Journal of Pedagogical Theory and Practice], 63(3), 381-394.386

Vasilijević, D. (2016). Social Networks In Education: Estimates and Expectations of Students, Teme, Vol. XL, No 4, p. 1241-1258 [ISSN 0353-7919; DOI 10.22190 /TEME1604241V; Online ISSN 1820-7804; COBISS.SR-ID 559631]. 


\title{
ИНТЕГРИСАЊЕ ДИГИТАЛНИХ ТЕХНОЛОГИЈА У НАСТАВНИ ПРОЦЕС
}

\author{
Биљана Новковић Цветковић, Драгана Станојевић \\ Универзитет у Нишу, Педагошки факултет у Врању, Врање, Србија
}

\section{Резиме}

Један од предуслова активног учешћа у савременом друштву, окарактерисаном као дигитално доба, јесте употреба дигиталних технологија. Научно-технолошким напретком и појавом нове информационе технологије створене су нове могућности да се пређе праг традиционалне организације наставе на наставу коју стварају нови дигитални медији.

Иновациони процес почиње од нове идеје, од знања које је резултат научних истраживања. Друга фаза иновационог процеса је увођење иновације у практичну употребу, а трећа је ширење иновација. Сврха образовне иновације је да помогне да образовање буде боље, да буде отворено, еластично, индивидуализовано, стваралачко, непрекидно. Снажан импулс унапређивању образовања могу дати савремене технологије учења: информатички приступ, ИЦТ, компјутерски програми, коришћење електронских мрежа. Прелазак са традиционалне на савремену дигиталну технологију доста је сложен и веома захтеван. Коришћењем савремених дигиталних технологија мења се и суштина саме наставе, мењају се педагошки приступи.

Својим разноликим могућностима дигитална технологија намеће се као изванредно средство за моделовање не само квалитетне и ефикасне наставе него и свих активности школе пред коју се учешћем у друштву стављају веома одговорни и изазовни задаци. Она задире у подручје садржаја образовања, у активност наставника̂, у наставне облике и методе, стилове учења ученика̂, евалуацијске процесе, у комплетан рад школе. Дигиталне технологије представљају најзначајније чиниоце унапређивања наставног рада у школи. Информатизација наставног рада увођењем моћне информационе технологије омогућује да се из основа измени традиционални концепт наставе. Дигиталне технологије чине основу за спровођење нове концепције наставе утемељене на информатичкој парадигми. Да би дигиталне технологије постале саставни део наставног процеса, оне морају бити прихваћене од стране наставника̂.

У овом раду показано је да наставници имају велико интересовање за примену дигиталних технологија у настави. Од свих наведених ставки, наставници у свом раду највише користе интернет садржаје. Наставници испољавају велику заинтересованост за употребу дигиталних технологија у свом раду. Млађи наставници исказали су ставове веће заинтересованости за примену дигиталних технологија у настави него старији наставници. 